\title{
Short Communication: Density and length-weight relationship of mudskipper (Periophthalmus spp.) in the mangrove area of Kairatu Beach, Maluku, Indonesia
}

\author{
DIANA TANIWEL ${ }^{1, \vartheta}$, FREDY LEIWAKABESSY ${ }^{2}$, DOMINGGUS RUMAHLATU ${ }^{2, \vee v}$ \\ ${ }^{1}$ Graduate Program of Biology Education, Universitas Pattimura. Jl. Dr. Tamaela, Ambon 97116, Maluku, Indonesia. Tel./fax.: +62-911-311803, "email: \\ dianataniwel2017@gmail.com \\ ${ }^{2}$ Program of Biology Education, Faculty of Teacher Training and Education, Universitas Pattimura. Jl. Ir. M. Putuhena, Ambon 97233, Maluku, \\ Indonesia. Tel./fax.: +62-911-3825216, ``email: dominggus_amq@yahoo.co.id
}

Manuscript received: 29 August 2020. Revision accepted: 27 October 2020.

\begin{abstract}
Taniwel D, Leiwakabessy F, Rumahlatu D. 2020. Short Communication: Density and length-weight relationship of mudskipper (Periophthalmus spp.) in the mangrove area of Kairatu Beach, Maluku, Indonesia. Biodiversitas 21: 5465-5473. Mudskippers (genus Periophthalmus) fish species inhabit mudflat, sandy beaches, and mangrove areas. Their daily activities are influenced by tidal rhythms. The aim of this research was to identify the species of mudskipper, their density, and length-weight relationship of more density species in the mangrove area of Kairatu beach, Maluku, Indonesia. This research was conducted from July to August 2018, 3 sampling sites using purposive sampling technique. The physical-chemical parameters of environmental conditions (temperature, dissolved oxygen, salinity, and $\mathrm{pH}$ of water) were measured directly on location (in-situ), while the different mudskippers species present in the study sites were identified in the laboratory at the Pattimura University. Quantitative data on population density and length and weight of individuals were obtained for four Periophthalmus species. The physical-chemical parameters of environmental conditions in the three sampling stations were within the range of optimal values previously obtained for mudskipper species. The temperatures ranged from 30.01-30.05 ${ }^{\circ} \mathrm{C}$, the dissolved oxygen ranged from 7.1-7.5 mg/L, the $\mathrm{pH}$ ranged from 7.3-7.5, and the salinity ranged from 5-7 \%o. The four mudskippers species identified in the sampling sites were (in density descending order): Periophthalmus argentilineatus (5.05 $\left.\mathrm{ind} / \mathrm{m}^{2}\right)$, P. gracilis $\left(1.5 \mathrm{ind} / \mathrm{m}^{2}\right), P$. malaccensis $\left(0.4 \mathrm{ind} / \mathrm{m}^{2}\right)$ and $P$. kalolo $\left(0.3 \mathrm{ind} / \mathrm{m}^{2}\right)$. The results of the regression analysis showed that there was no significant relationship between physical-chemical parameters to mudskipper density. The results of the length-weight relationship of the two most abundant species $P$. argentilineatus and $P$. gracilis a negative allometric length-weight relationship (b<3), while the $P$. kalolo and $P$. malaccensis indicated a positive allometric growth type ( $\mathrm{b}>3)$.
\end{abstract}

Keywords: environmental factor, density, length-weight relationship, mudskipper

\section{INTRODUCTION}

The Maluku archipelago Indonesia is composed of 1.340 islands with a coastline of $10.630,10 \mathrm{~km}$, and an ocean area of $58.294 \mathrm{~km}^{2}(92.4 \%)$ (Huliselan et al. 2017). Coastal areas are known to be very dynamic with rapid biological, chemical and geological changes (Sukardjo and Pratiwi 2015), and have various ecosystems, such as small island ecosystems (Haeril and Purnomo 2019), estuary ecosystems, alga ecosystems, coral reefs, seagrass ecosystems (Sukardjo 2004), and mangrove ecosystems (Sofian et al. 2019). Mangrove ecosystems have a very high level of productivity compared to the other ecosystems in coastal areas (Lee et al. 2014). This is because mangrove ecosystems are inhabited by various biota such as gastropods (Nugroho et al. 2019; Rumahlatu and Leiwakabessy 2017), Polychaeta (Pamungkas 2017), crustaceans (Tetelepta et al. 2018; Dewiyanti et al. 2018), echinoderms (Setyastuti et al. 2018), and various species of fish (Feka and Manzano 2008; Hanifah and Eddiwan 2018; Wahyudewantoro 2018).

Mudskipper (Periophthalmus spp.) species belongs to the class Actinopterygii, order Perciformes, family Gobiidae (WoRMS 2018; Fishbase 2018; Clayton 1993), and occupies primary (organisms that obtain energy from producers) and secondary positions (organisms that obtain energy from primary consumers) in the food chain despite their very small size (Polgar and Lim 2011) inhabiting muddy habitats, sandy beaches, and mangrove areas (Takita et al. 2011). Mudskipper daily behavior is closely related to tidal rhythm (Ravi 2011; Muhtadi et al. 2016) where they climb mangrove roots, walk-on mudflats, and dig burrows in mud (Bhatt et al. 2009; Al-Behbehani and Ebrahim 2010; Polgar and Lim 2011).

There has been many research on mudskippers, and this fish is reported to be found in various aquatic ecosystems. Seven mudskipper species (Boleophthalmus pectinirostris, B. boddarti, Periophthalmodon schlosseri, Periophthalmus gracilis, P. chrysospilos, P. variabilis, and Scartelaos histophorus) were found in coastal waters of Malaysia (Polgar and Crosa 2009). In addition, P. malaccensis had a relatively limited geographical distribution and was found in the waters of Singapore, the Philippines, the Maluku Islands, western New Guinea, and Northern Sulawesi (Polgar 2016; Fishbase 2018). P. takita was found in East India, the Western Pacific to Northern Australia (Jaafar and Larson 2008; Fishbase 2018). P. argentilineatus was found in Indo-Pacific waters (Red Sea, South Africa, Marianas, 
and Samoa), Ryukyu Islands, Western Australia and Oceania (Fishbase 2018; Polgar 2014). P. kalolo was spread throughout the Atlantic coast of Africa, the IndoPacific region, and Samoa (Polgar 2014; Fishbase 2018). $P$. gracilis was found in the coast of Malaysia (Polgar 2008; Khaironizam and Norma-Rashid 2002), in the Samas Beaches, Yogyakarta, Indonesia (Supriyati et al. 2019). Almost 24 species of mudskipper are found in Indonesian coastal waters, and 8 of them are found in Maluku Islands (Boleophthalmus boddarti, Periophthalmodon freycineti, $P$. schlosseri, Periophthalmus argentilineatus, $P$. gracilis, $P$. kalolo, P. malaccensis, Scartelaos histophorus) (Pormansyah et al. 2019).

In addition, some environmental parameters such as $\mathrm{pH}$, temperature, and salinity are correlated with the density of mudskipper (Kanejiya et al. 2017). Mahadevan and Ravi (2015) found that mudskipper can survive within a range of 23.5-35.3 ${ }^{\circ} \mathrm{C}$ of temperature, 24.4-34.4 psu of salinity, and 3.8-8.17 $\mathrm{mg} / \mathrm{L} \mathrm{pH}$. On the other hand, previous studies showed that the length-weight relationship of male mudskipper $B$. pectinirostris presented negative allometric growth $(b<3)$, but positive allometric growth $(b>3)$ for females (Sunarni et al. 2019); P. barbarus showed negative allometric growth (Chukwu and Deekae 2010) and B. boddarti showed isometric growth (Quang 2014). Based on the results of their research, it was revealed that this study is still partially explained about the environmental factors, density, and the length-weight relationships of mudskippers. Therefore, this research aims at determining the species of mudskipper, density, and length-weight relationship. The information about the environmental factors, density, relationship of physical-chemical parameters to mudskipper density, and length-weight relationship of mudskippers could be used as an indicator of the sustainability of mangrove habitats.

\section{MATERIALS AND METHODS}

\section{Study sites}

The research was conducted in July-August 2018 at the coordinates $3^{\circ} 34^{\prime} 72^{\prime \prime} \mathrm{S}, \quad 1^{\circ} 38^{\circ} 17^{\prime \prime} \mathrm{E}$ to $3^{\circ} 36^{\prime} 28^{\prime \prime} \mathrm{S}$, $128^{\circ} 37^{\prime} 05^{\prime \prime} \mathrm{E}$ in the coastal waters of Kairatu village beach, with station 1: Kairatu village beach, station 2: WaitasiKairatu village beach, station 3: Talaga-Kairatu village beach (Figure 1). The data collection stations were determined using the purposive sampling technique, based on mudskipper habitat in the mangrove area.

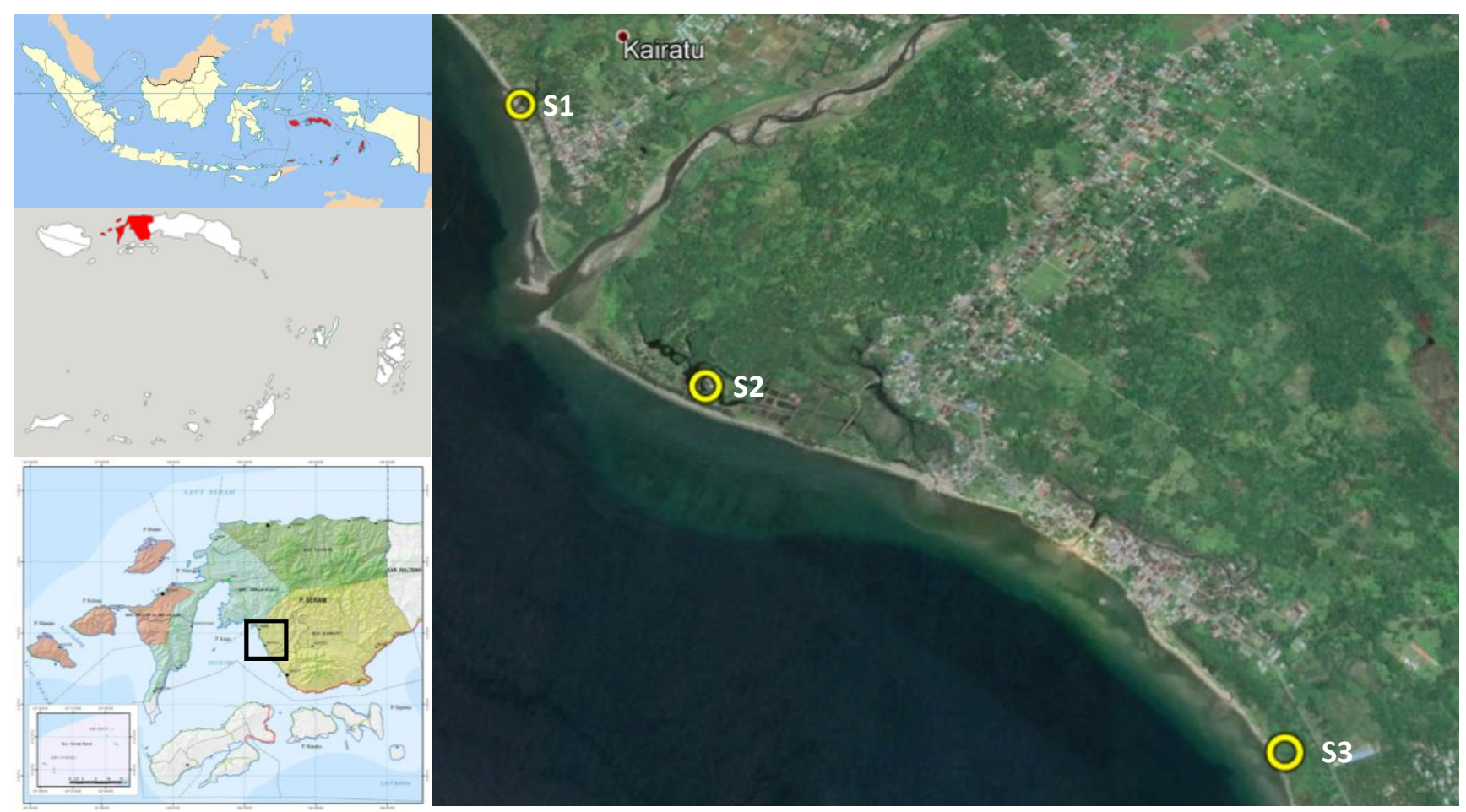

Figure 1. Map of the study area showing the location of the sampling sites. Note: S: station. S1: Kairatu village beach, S2: WaitasiKairatu village beach, S3: Talaga-Kairatu village beach 


\section{Sampling procedure}

The mudskipper samples were sampled by following the procedure as follows: (i) The mangrove area in the Kairatu village beach was divided into 3 observation stations. After that, when the seawater receded, three transects with a size of $4 \times 5 \mathrm{~m}^{2}$ were created at each observation station, and a quadrant with a size of $2 \times 2 \mathrm{~m}^{2}$ was made at each transect. (ii) The physical-chemical parameters of the aquatic environment (temperature, DO, salinity, and $\mathrm{pH}$ ) were measured directly on location (in-situ) at each observation station for 3 measurements. (iii) Mudskipper sampling was done 3 times during the study and was using a mesh with a size of 1.75 inches. (iv) Next, the mudskipper samples were put into an ethylene plastic bag and labeled. (v) The mudskipper samples were put into iceboxes and then taken to the laboratory for identification, and length and weight measurements. The mudskippers were identified based on the database Fishbase (2018) and WoRMS (2018), as well as species descriptions provided by Murdy (1989), Kottelat (2013), and Larson et al. (2016).

\section{Data analysis}

The data were descriptively analyzed to illustrate the physical-chemical conditions of the environment and the mudskipper density. Furthermore, the analysis of the relationship between physical-chemical factors and density used simple linear regression analysis with $\alpha=0.05$.

The data of the mudskipper density were obtained from the calculation using the formula by Odum and Barrett (2004), as follows.

$$
\begin{aligned}
& \begin{array}{l}
\text { Absolute } \\
\text { density }
\end{array}=\frac{\text { The number of individuals of each species }}{\text { The number of individuals of all species }} \\
& \begin{array}{l}
\text { Relative } \\
\text { density }
\end{array}=\frac{\text { The number of individuals of each species }}{\text { The number of individuals of all species }} \times 100
\end{aligned}
$$

The length-weight relationship of mudskippers was calculated using the formula by Khaironizam and NormRashid (2002).

$$
\begin{aligned}
& \begin{array}{l}
\mathrm{W}=\mathrm{aL}^{\mathrm{b}} \\
\log \mathrm{W}=
\end{array} \\
& \text { Where: } \\
& \text { W } \mathrm{a}+\mathrm{b} \log \mathrm{L} \\
& \mathrm{L} \quad \text { : Total weight of mudskipper }(\mathrm{g}) \\
& \mathrm{a} \text { and } \mathrm{b} \quad \text { : Constanta length of mudskipper }(\mathrm{cm})
\end{aligned}
$$

The criteria for determining the length-weight relationship of mudskipper Effendie (1997): (1) If the value of $b=3$, then it indicates isometric growth pattern (the length growth is the same as the weight growth). (2) If the value of $b \neq 3$, then it indicates the allometric growth pattern: (a) If $b>3$, then it indicates the positive allometric growth pattern (weight growth is more dominant) and (b) If $\mathrm{b}<3$, then it indicates the negative allometric growth pattern (length growth is more dominant). The parameters $a$ and $b$ were calculated by least-squares regression (coefficient of determination/ R2).

\section{RESULTS AND DISCUSSION}

\section{Physical-chemical parameters of the environment}

The results of the measurement of the physicalchemical parameters of the environment (Table 1) revealed that temperature, dissolved oxygen, and water $\mathrm{pH}$ at the three research stations were very similar, but not salinity. The range of the temperatures was between 30.01-30.05 ${ }^{\circ} \mathrm{C}$, with the highest temperature was at station $1\left(30.05^{\circ} \mathrm{C}\right)$ and the lowest temperature was at station $3\left(30.01^{\circ} \mathrm{C}\right)$. Several previous studies revealed that the water temperature suitable for mudskipper life was in the range of $23.5-35.5^{\circ} \mathrm{C}$ (Ravi 2011; Mahadevan and Ravi 2015; Akinrotimi et al. 2019). This indicates that the range of temperatures in the mangrove area of Kairatu village was in the optimal range for mudskipper. In addition, temperature also has a close relationship with the presence of dissolved oxygen in waters, because an increase in temperature will affect the increase in oxygen consumption by aquatic organisms (Roman et al. 2019; Giomi et al. 2019). Varadharajan et al. (2013) and Nursyam (2017) explained that temperature, dissolved oxygen, $\mathrm{pH}$, and salinity have a significant effect on the survival and productivity of various marine biota.

The results of the DO measurements (Table 1) indicated that the dissolved oxygen (DO) ranged from 7.1-7.5 mg/L, with the highest DO was at station $1(7.5 \mathrm{mg} / \mathrm{L})$ and the lowest DO was at station $2(7.0 \mathrm{mg} / \mathrm{L})$. According to Kho et al. (2020) DO levels for biota life in waters are 5-16.1 $\mathrm{mg} / \mathrm{L}$. Akinrotimi et al. (2019) reported that mudskipper could survive in the DO levels of 4.22-5.89 mg/L in rivers. It shows that DO has a significant influence on the presence of mudskippers in mangrove ecosystems, where there was a large number of mudskipper individuals found at station 1, when compared to other stations. Several researchers described that dissolved oxygen is a parameter that reflects the quality of aquatic ecosystems (Gholizadeh et al. 2016; Siriwardana et al. 2019; Zaghloul et al. 2019). Moreover, dissolved oxygen is needed for metabolic processes to produce energy which uses for the growth and reproduction of organisms (Ekau et al. 2010; Stevens and Gobler 2018). This means that dissolved oxygen has a significant effect on the life of mudskippers in mangrove ecosystems (Mahadevan and Ravi 2015).

The results of the $\mathrm{pH}$ measurements (Table 1) indicate that the $\mathrm{pH}$ ranged from 7.3-7.5, with the highest $\mathrm{pH}$ was at station 3 (7.5) and the lowest $\mathrm{pH}$ was at station 2 (7.3). The value of $\mathrm{pH}$ which is still tolerable for aquatic biota ranges is from 7-8.5 (Berge et al. 2010). Some researchers reported that the suitable $\mathrm{pH}$ levels in aquatic ecosystems for mudskipper life range from 7-8 (Ip et al. 2004), 5.8-6.5 (Ravi 2011), 7.1-8.1 (Elviana et al. 2019), 6.33-6.52 (Akinrotimi et al. 2019), 6.5-7.3 (Tanjung et al. 2019). This indicates that the $\mathrm{pH}$ levels in these research locations were still in a suitable range for the life of mudskippers.

The results of the salinity measurements (Table 1) indicate that the salinity ranged from 5-7\%, with the highest salinity was at station $2(7 \%$ ) and the lowest salinity was at station $3(5 \%)$. The results of this research indicated that the salinity of the mangrove area varied 
greatly. According to Yuvaraj et al. (2017), the salinity of mangrove areas ranges between 6-32 PSU. In addition, Koprivnikar and Poulin (2009) confirm that marine organisms are able to survive at salinity up to 35 PSU. Different suitable salinity ranges have been reported for mudskippers inhabiting in mangrove areas from 5 to $18 \%$ (Dobson and Frid 2009) and form 10.01 to $14.88 \%$ (Akinrotimi et al. 2019). This shows that the range of the salinity reported in our research was within a suitable range previously reported. Nevertheless, Ravi (2011) reports that mudskipper can survive in mangrove areas with a salinity range of 23.5-32.8\% $\%$. According to Mai et al. (2019) that salinity affects the life of mudskippers in their habitat.

\section{Species of mudskipper}

Four mudskipper species were found in the sampling area (Table 2, Figure 2), namely $P$. argentilineatus (266 individuals), $P$. gracilis (52 individuals), $P$. kalolo (11 individuals), and $P$. malaccensis (11 individuals). Interestingly, Periophthalmus is the only genus of mudskipper found in this area. According to Indarjo et al. (2020) and Ansari et al. (2014), the mudskipper from the genus Periophthalmus is endemic to the mangrove area, and not found in many places. This means that the mangrove area in the Kairatu beach is an endemic area for the genus Periophthalmus.

Periophthalmus argentilineatus. The identification results of $P$. argentilineatus are shown that the body of this mudskipper is brown to dark brown, has silver vertical stripes on the sides of its abdomen, and striking irregular black striped patterns on the body parts. The lower abdomen is white, and the first dorsal fin is convex with a black line and many small white spots. There are 13-15 fish bones on the first dorsal fin, and their habitat is in the mangrove roots. According to Murdy (1989), the body of $P$. argentilineatus is brown, the stomach is silvery-white, the head is dark brown with the ventral and pectoral parts of the head silvery-white, many small white spots on the head, the dorsal part is wrapped in red with an extending wide black line, the caudal fin has many brownish-red spots, blackish pectoral fins; anal and pelvic fins are white, and ventral peritoneum is black. Takita et al. (2011) explained that $P$. argentilineatus lives in sediments, rocks, and mangrove roots and stems. It is probably the reason for a large number of $P$. argentilineatus in the mangrove area of the study sites (Table 2). In addition, the large number of the $P$. argentilineatus individuals was also affected by their growth patterns with limited pollution levels, tidal conditions, and seasonal factors (Kruitwagen et al. 2006). $P$. argentilineatus ways of life cause a large number of individuals to be found in the mangrove area of Kairatu beach. In addition, the dominance of $P$. argentilineatus in the mangrove areas is affected by the presence of food in the form of mangrove crabs (Kruitwagen et al. 2007).
Periophthalmus gracilis. The identification results of $P$. gracilis are shown that the body is grayish-brown and has slanted brown lines and silvery gray spots on the body. The lower abdomen is white. The first dorsal fin is rounded short brown which ends up being a clear black spot on the back with 10 thorns of the first dorsal fin. Its habitat is under mangrove trees and in mudflats when the sea water is receding. Muhtadi et al. (2016) and Murdy (1989) explained that the back part of its body is grayish brown, the abdomen is white, and it has slanted dark brown lines and silvery gray spots on the body. According to Jaafar et al. (2016), the description of $P$. gracilis is very similar to that of $P$. pusing in the Lesser Sunda İslands, where there are black spots on the posterior part of the first dorsal fin, the first dorsal fin is higher than the depth of the body in the anus, and the inter dorsal distance is less than half the length of the spine of the first dorsal fin.

Periophthalmus kalolo. The results of identification are shown that $P$. kalolo has dark brown to black body, with many small white spots on the cheeks, and does not have a silver color like the $P$. argentilineatus. The first dorsal fin does not have white spots, it has a thick black line at the tip, and the lower part of the abdomen is yellowish-white. There are 9-12 thorns on the first dorsal fin, and their habitat is on mangrove roots and rocks. According to Murdy (1989), P. kalolo has brownish-gray body color, head with many white spots and irregular black spots, caudal fin with black spots, immaculate anal fin; pectoral fins and abdominal fin blackish with grayish spots. In addition, Enot et al. (2015) explained that $P$. kalolo has frenum on the abdominal fin, the lower part of the fin is joined by a membrane around $3 / 4$ of the radius of the fin; the first dorsal fin is slightly rounded with a black line at the edge and white spots at the base; the second dorsal fin has a black line.

Table 1. The results of the measurements of the physicalchemical parameters of the environment

\begin{tabular}{lcccc}
\hline Stationary & $\begin{array}{c}\text { Temperature } \\
\left({ }^{\mathbf{}} \mathbf{C}\right)\end{array}$ & $\begin{array}{c}\text { DO } \\
(\mathbf{m g} / \mathbf{L})\end{array}$ & $\begin{array}{c}\text { Salinity } \\
(\mathbf{\%})\end{array}$ & $\mathbf{p H}$ \\
\hline Kairatu village & 30.05 & 7.5 & 6.0 & 7.3 \\
beach & 30.04 & 7.5 & 6.0 & 7.5 \\
& 30.06 & 7.5 & 6.0 & 7.4 \\
Average & $30.05 \pm 0.01$ & $7.5 \pm 0.00$ & $6.0 \pm 0.00$ & $7.4 \pm 0.10$ \\
& & & & \\
Waitasi & 30.02 & 7 & 7.0 & 7.3 \\
Kairatu village & 30.04 & 7 & 7.0 & 7.3 \\
beach & 30 & 7 & 70 & 7.3 \\
Average & $30.02 \pm 0.02$ & $7.0 \pm 0.00$ & $7.0 \pm 0.00$ & $7.3 \pm 0.00$ \\
& & & & \\
Talaga-Kairatu & 30.00 & 7.2 & 5.0 & 7.5 \\
village beach & 30.02 & 7.0 & 5.0 & 7.5 \\
& 30.01 & 7.1 & 5.0 & 7.5 \\
Average & $30.01 \pm 0.01$ & $7.1 \pm 0.10$ & $5.0 \pm 0.00$ & $7.5 \pm 0.00$ \\
\hline
\end{tabular}

Table 2. Species of mudskipper found in the mangrove area of Kairatu beach

\begin{tabular}{lcccc}
\hline \multicolumn{1}{c}{ Mudskipper } & \multicolumn{3}{c}{ Number of mudskippers per station } & Total \\
\cline { 2 - 4 } & Station 1 & Station 2 & Station 3 & 67 \\
P. argentilineatus (Valenciennes, 1837) & 98 & 101 & 11 & 266 \\
P. gracilis (Eggert, 1935) & 30 & 11 & 1 & 52 \\
P. kalolo (Lesson, 1831) & 4 & 6 & 2 & 11 \\
P. malaccensis (Eggert, 1935) & 1 & 8 & 11 \\
\hline
\end{tabular}



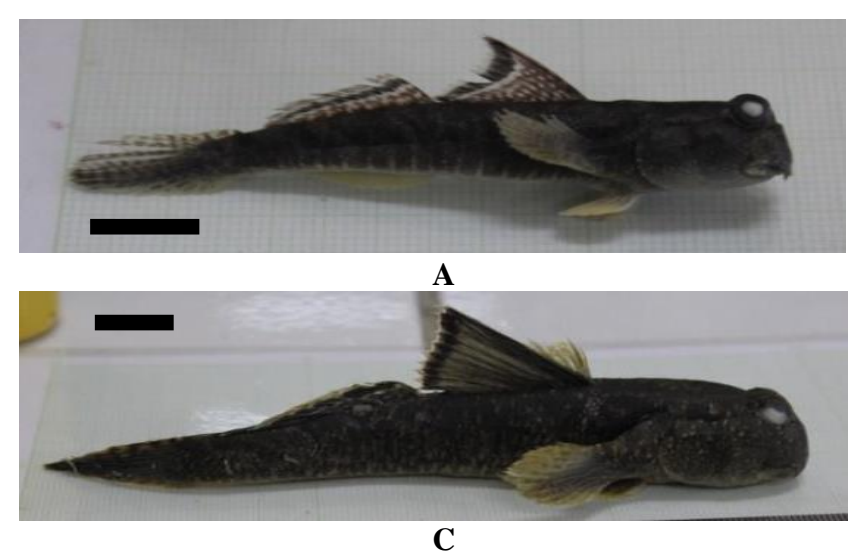

Figure 2. Mudskippers from the mangrove area of Kairatu beach. A. Periophthalmus argentilineatus, B. P. gracilis, C. P. kalolo, D. P. malaccensis. $\mathrm{Bar}=1 \mathrm{~cm}$
Periophthalmus malaccensis. The identification results of identification show that $P$. malaccensis has brown to black body. The lower part of the abdomen is white to gray. The first fin is rounded and the thorn of the first dorsal fin protrudes outward, it has small white spots and there are 10-12 thorns of the first dorsal fin. It inhabits mangrove roots and mudflats when the seawater is receding. According to Murdy (1989), P. malaccensis has a dark brown body color, a head with many small white spots on the abdomen, blackish spots on the caudal fin, anal fin with narrow white and black margins, a blackish pectoral fin, abdominal fins with narrow white and black margins. In addition, Polgar (2016) explained that $P$. malaccensis has (i) a square-shaped abdominal fin with protruding pelvic frenum, partially joined by a base membrane, both pigmented in the internal parts and the back, and with white margins; (ii) the presence of dark pigmentation on the anal interradial membrane; (iii) sky blue spots on the cheeks and opercula; (iv) protruding transverse folds of the snout; and (v) having the first backbone.

\section{Density of mudskipper}

The mudskipper $P$. argentilineatus had the highest absolute density and relative density at all sampling stations (Table 3). Station 3 presented the highest values and station 2 the lowest. This shows that the ability of an organism to adapt to its environment has an effect on the high density of the organism (Hoffmann and Hercus 2000; Odum and Barrett (2004). According to Ansari et al. (2014), the population density of mudskipper significantly depends on its tolerance to environmental changes and substrate differences of mangrove areas. Kanejiya et al. (2017) confirmed that environmental parameters such as the depth of the mud layer, sediment composition, $\mathrm{pH}$, temperature and salinity, have a significant effect on the distribution of mudskipper in sea waters.

Mudskipper $P$. malaccensis and $P$. kalolo had the lowest absolute density at station 1 and station 3, while $P$. malaccensis had the lowest relative density at station 1 . Mudskipper $P$. gracilis had the lowest absolute density at station 2 and station 3 . The low population density of $P$. malaccensis, $P$. kalolo, and $P$. gracilis was influenced by the waste disposal of sago processing and the research
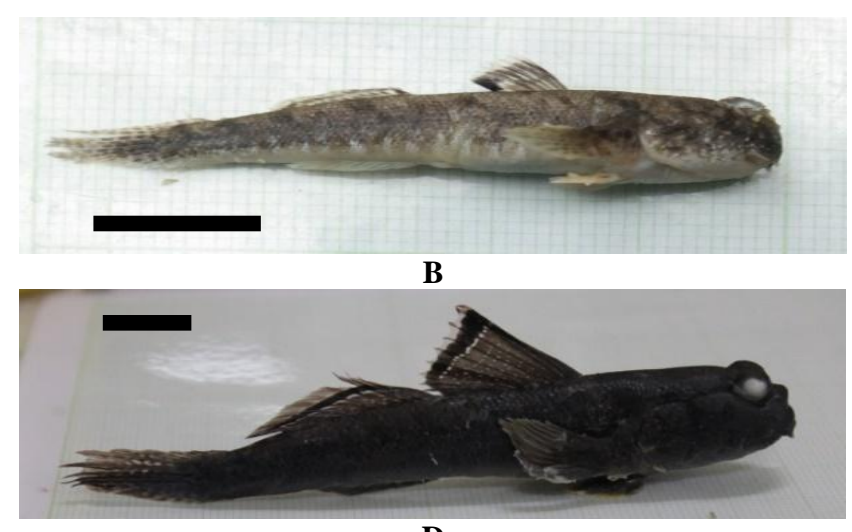

D locations which was close to market activities. In addition, some researchers revealed that the lack of diatomic food (Ravi 2011) and rather hard sedimentary composition (Kanejiya et al. 2017; Polgar et al. 2017) resulted in low population density of mudskipper species.

\section{Relationship of physical-chemical parameters to mudskipper density}

The results of the regression analysis of physicalchemical parameters (temperature, DO, salinity, and $\mathrm{pH}$ ) to mudskipper density indicate that there is no significant relationship. This shown by the sig value $p>0.05$ so that the physical-chemical parameters at the three research locations do not affect the mudskipper density $P$. argentilineatus, $P$. gracilis, $P$. kalolo, and $P$. malaccensis (Table 4). This shows that the mudskipper can adapt to the environment with various physical-chemical parameters. Rumahlatu et al (2020) reported that $P$. argentilineatus, $P$. kalolo, and $P$. minutus in mangrove forest area of Ambon Island lived in a temperature range of $26-27{ }^{\circ} \mathrm{C}, \mathrm{pH}$ range of 7.7-7.9, and salinity range of 27-28 \% . Mahadevan and Ravi (2015) reported that the genus Periophthalmus on the southeast coast of India lives at $23.5-35.3^{\circ} \mathrm{C}$, salinity $24.4-$ 34.4 PSU, $\mathrm{pH}$ with a value of 8.17 in summer while 7.67 in the rainy season, DO water varies from $3.83-5.17 \mathrm{mg} / \mathrm{L}$.

\section{Length-weight relationship of mudskipper}

The calculation results of the length-weight relationship in mudskipper $P$. argentilineatus, $P$. gracilis, $P$. kalolo, and $P$. malaccensis indicated that all four species have varying length and weight growth patterns. $P$. argentilineatus and $P$. gracilis have a negative allometric length-weight relationship $(\mathrm{b}<3)$, whereas $P$. kalolo, and $P$. malaccensis are positive allometric length-weight relationship (b>3) (Table 5 and Figure 3). The research by Khaironizam and Norma-Rashid (2002) have found that Scartelaos histophorus, $P$. chrysospilos, $P$. gracilis, $P$. novemradiatus, and $P$. septemradiatus had negative allometric growth patterns $(\mathrm{b}<3)$, whereas $P$. argentilineatus and $P$. spilotus had positive allometric growth patterns $(b>3)$. The negative allometric growth of $P$. papilio is shown that the body length grows faster than the body weight, resulting in more flattened mudskipper (Moslen and Daka 2017). 
Table 3. Results of calculation of mudskipper density

\begin{tabular}{|c|c|c|c|c|}
\hline Station & Species & Number of individuals & Absolute density (ind $/ \mathbf{m}^{2}$ ) & Relative density (\%) \\
\hline \multirow{6}{*}{ Kairatu village beach } & $P$. argentilineatus & 98 & 4.9 & 73.68 \\
\hline & $P$. gracilis & 30 & 1.5 & 22.56 \\
\hline & P. kalolo & 4 & 0.2 & 3.01 \\
\hline & P. malaccensis & 1 & 0.05 & 0.75 \\
\hline & Total & 133 & 6.65 & 100 \\
\hline & Average & $33.25 \pm 45.09$ & $1.66 \pm 2.25$ & $25.00 \pm 33.90$ \\
\hline \multirow[t]{6}{*}{ Waitasi-Kairatu village beach } & $P$. argentilineatus & 101 & 5.05 & 80.16 \\
\hline & P. gracilis & 11 & 0.55 & 8.73 \\
\hline & P. kalolo & 6 & 0.3 & 4.76 \\
\hline & P. malaccensis & 8 & 0.4 & 6.35 \\
\hline & Total & 126 & 6.3 & 100 \\
\hline & Average & $31.50 \pm 46.38$ & $1.58 \pm 2.32$ & $25.00 \pm 36.81$ \\
\hline \multirow[t]{6}{*}{ Talaga-Kairatu village beach } & $P$. argentilineatus & 67 & 3.35 & 82.71 \\
\hline & $P$. gracilis & 11 & 0.55 & 13.59 \\
\hline & P. kalolo & 1 & 0.05 & 2.47 \\
\hline & P. malaccensis & 2 & 0.1 & 1.23 \\
\hline & Total & 81 & 9.05 & 100 \\
\hline & Average & $20.25 \pm 31.49$ & $2.26 \pm 1.57$ & $25.00 \pm 38.87$ \\
\hline
\end{tabular}

Tabel 5. Length, weight, and length-weight relationship parameters of mudskipper

\begin{tabular}{|c|c|c|c|c|c|c|}
\hline \multirow{2}{*}{ Species } & \multirow{2}{*}{$\begin{array}{c}\text { Max Length } \\
(\mathbf{m m})\end{array}$} & \multirow{2}{*}{ Max Weight (g) } & \multicolumn{3}{|c|}{ L-W relationship $\left(\mathbf{W}=\mathbf{a L}^{\mathbf{b}}\right)$} & \multirow{2}{*}{ Growth type } \\
\hline & & & $\mathbf{a}$ & b & $\mathbf{R}^{2}$ & \\
\hline P. argentilineatus & 7.70 & 9 & 0.0089 & 2.9865 & 0.9677 & Negative allometric \\
\hline P. gracilis & 1.66 & 5.5 & 0.014 & 2.6153 & 0.4416 & Negative allometric \\
\hline P. kalolo & 28.41 & 13.9 & 0.0046 & 3.2958 & 0.9914 & Positive allometric \\
\hline P. malaccensis & 5.35 & 8.5 & 0.0029 & 3.4534 & 0.3217 & Positive allometric \\
\hline
\end{tabular}

Note: a: correlation constant, b: regression coefficient or length exponent, R: correlation coefficient, $\mathrm{R}^{2}$ : square of correlation coefficient

Table 4. Result of relationship of physical-chemical parameters to mudskipper density

\begin{tabular}{llllll}
\hline \multicolumn{1}{c}{ Species } & $\begin{array}{c}\text { Physical- } \\
\text { chemical } \\
\text { parameters }\end{array}$ & R & $\mathbf{R}^{\mathbf{2}}$ & $\mathbf{F}$ & Sig. \\
\hline P. argentilineatus & Temperature & .634 & .402 & .671 & .563 \\
& DO & .251 & .063 & .067 & .838 \\
& Salinity & .903 & .816 & .4423 & .283 \\
& pH & .903 & .816 & .4423 & .283 \\
P. gracilis & Temperature & .971 & .942 & 16.333 & .154 \\
& DO & .982 & .964 & 27.000 & .121 \\
& Salinity & .000 & .000 & .000 & 1.000 \\
P. kalolo & pH & .000 & .000 & .000 & 1.000 \\
& Temperature & .350 & .122 & .140 & .772 \\
& DO & .075 & .006 & .006 & .952 \\
& Salinity & .993 & .987 & 75.000 & .073 \\
& pH & .993 & .987 & 75.000 & .073 \\
& Temperature & .402 & .161 & .193 & .737 \\
& DO & .749 & .561 & 1.276 & .461 \\
& Salinity & .792 & .628 & 1.688 & .418 \\
& pH & .792 & .628 & 1.688 & .418 \\
\hline
\end{tabular}

In addition, Sunarni et al. (2019) revealed that negative allometric growth is influenced by the mudskipper swimming activity, thereby causing absorption of nutrients to reduce body weight. According to Ridho et al. (2019) and Akinrotimi et al. (2019) mudskipper do not grow in the same proportion, where the increase in length is faster than that in weight. Similarly, Quang (2016) suggested that the length-weight growth of $P$. schlosseri was negative allometric $(b<3)$, because it was influenced by the season and environmental factors. Furthermore, Mahadevan et al. (2019) also reported that $P$. elongatus showed negative allometric growth. Moreover, previous research conducted by Quang (2016) revealed that seasonal changes and environmental factors had a significant effect on the mudskipper growth. 


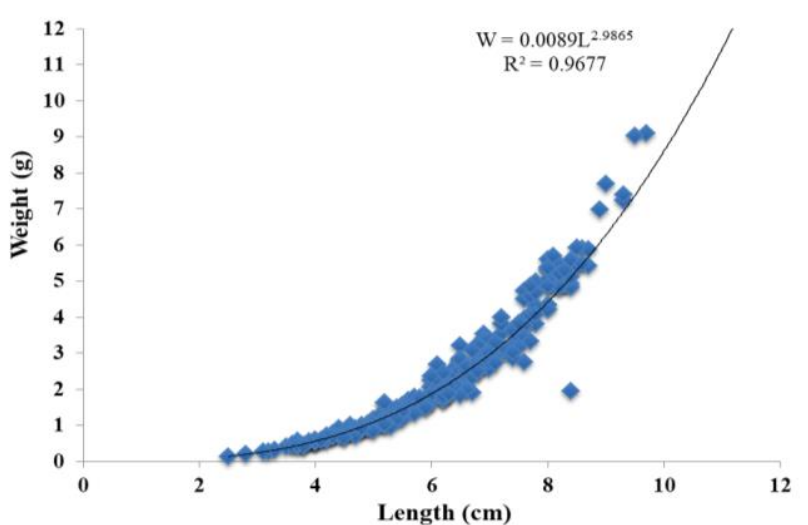

A

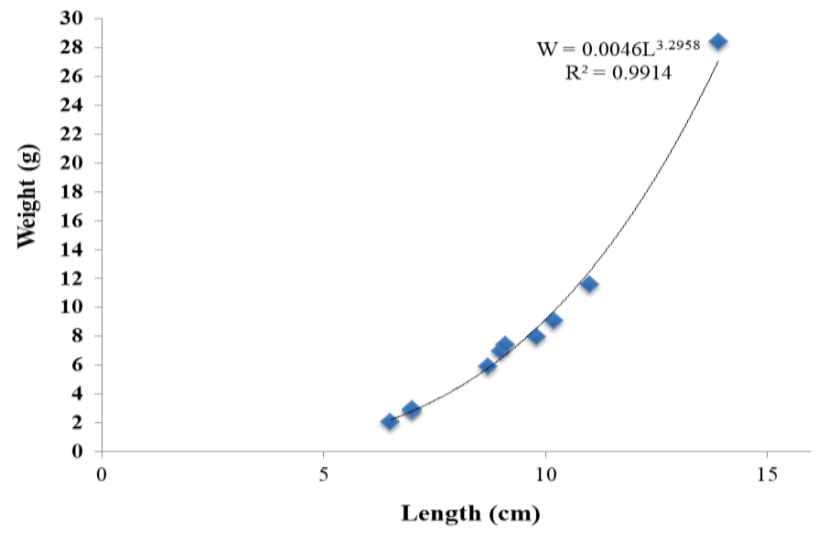

C

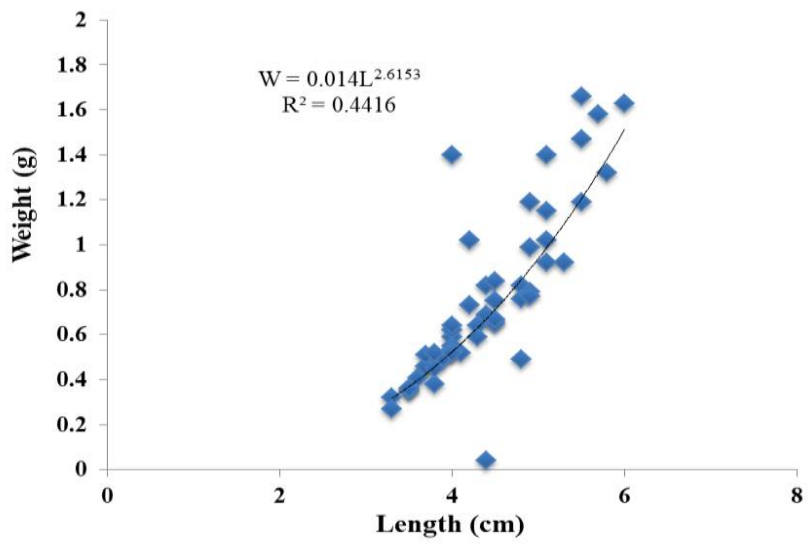

B

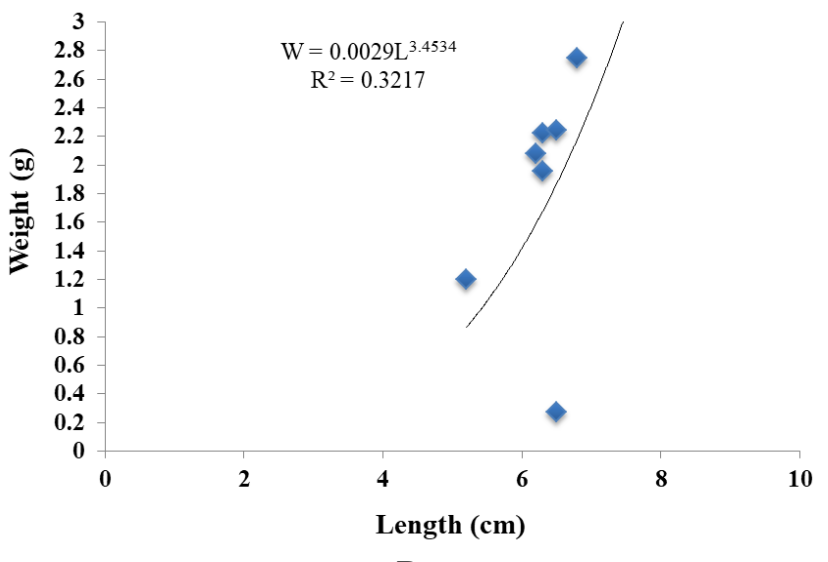

D

Figure 3. The length-weight relationship of mudskipper. A. Periophthalmus argentilineatus, B. P. gracilis, C. P. kalolo, D. P. malaccensis

Thus, it can be concluded that the increase in length has a significant effect on the increase in weight. Similarly, Sunarni et al. (2019) also found that female $B$. pectinirostris has positive allometric growth patterns with determination coefficient value of $\left(\mathrm{R}^{2}=0.9796-0.9784\right)$, where there was a strong correlation between the length and the weight of $B$. pectinirostris. Positive allometric growth of mudskipper was also found in male $P$. barbarous (Indarjo et al. 2020), P. argentilineatus and P. spilotus (Khaironizam and Norma-Rashid 2002), and P. crysospilos (Abdullah and Zain 2019). However, the determination coefficient value of $\left(\mathrm{R}^{2}=0.3217\right)$ (Table 5 and Figure 3 ) indicated that the length-weight relationship of $P$. malaccencis was very weak. Therefore, it can be concluded that the increase in length is not necessarily followed with the increase in weight. Similarly, the research conducted by Ridho et al. (2019) also shows that the P. schlosseri has a positive allometric growth pattern with the determination coefficient value of $\left(\mathrm{R}^{2}=0965\right)$, where the increase in body weight is faster than that in body length.

In conclusion, there are four types of mudskipper have found with different density levels, from high to low, namely $P$. argentilineatus $\left(5.05 \mathrm{ind} / \mathrm{m}^{2}\right), P$. gracilis $(1.5$ ind $\left./ \mathrm{m}^{2}\right), P$. malaccensis $\left(0.4 \mathrm{ind} / \mathrm{m}^{2}\right)$ and $P$. kalolo $(0.3$ ind $\left./ \mathrm{m}^{2}\right)$. Moreover, the $P$. argentilineatus and $P$. gracilis were had a negative allometric length-weight relationship $(\mathrm{b}<3)$, while the $P$. kalolo and $P$. malaccensis had a positive allometric length-weight relationship ( $b>3)$. In addition, temperature, dissolved oxygen, salinity, and water $\mathrm{pH}$ of the study sites were very suitable for the life of mudskipper, with the ranges of $30.01-30.05^{\circ} \mathrm{C}, 7.1-7.5$ $\mathrm{mg} / \mathrm{L}, 7.3-7.5$, and 5-7 \%o, respectively.

\section{ACKNOWLEDGEMENTS}

The authors would like to thank the Head of the Biology Laboratory, Pattimura University, Ambon, Indonesia for granting and the permission to use the laboratory facilities for the examination and identification of mudskipper specimens.

\section{REFERENCES}

Abdullah MIC, Zain KMD. 2019. Length-weight relationships, condition factor and growth parameters of Periophthalmus chrysospilos (Bleeker, 1852) (Gobiiformes: Gobiidae) in Bayan Bay, Penang, Malaysia. Sains Malays 48 (2): 271-279. DOI: 10.17576/jsm-20194802-02 
Akinrotimi OA, Amachree D, Azunna CG. 2019. Length-weight relationship of mudskipper, Periophthalmus barbarus (Bloch and Schneider 1801), from Buguma creek, Rivers State. Intl J Fish Aquat Res 4 (1): 75-79.

Al-Behbehani BE, Ebrahim H MA. 2010. Environmental studies on the mudskippers in the intertidal zone of Kuwait Bay. Nat Sci 8: 79-87.

Ansari AA, Trivedi S, Saggu S, Rehman H. 2014. Mudskipper: A biological indicator for environmental monitoring and assessment of coastal waters. J Entomol Zool Stud 2 (6): 22-33

Berge T, Daugbjerg N, Andersen BB, Hansen PJ. 2010. Effect of lowered $\mathrm{pH}$ on marine phytoplankton growth rates. Mar Ecol Prog Ser 416: 79-91. DOI: 10.3354/meps08780

Bhatt NY, Patel SJ, Patel DA, Patel PH. 2009. Burrowing activities of goby fish in the recent intertidal mud flats along the Navinal Coast, Kachchh, Western India. J Geol Soc India 74: 515-530. DOI 10.1007/s12594-009-0159-9.

Chukwu KO, Deekae SN. 2010. Length-weight relationship, condition factor and size composition of Periophthalmus barbarus (Linneaus 1766) in New Calabar River, Nigeria. Agric Biol J N Am 2 (7): 1069 1071. DOI: 10.5251/abjna.2011.2.7.1069.1071

Clayton DA. 1993. Mudskippers. Oceanogr Mar Biol Ann Rev 31: 507577

Dewiyanti I, Suryani D, Nurfadillah N. 2018. Community structure of crustacean in mangrove ecosystem rehabilitation in Banda Aceh and Aceh Besar district, Indonesia. IOP Conf Ser Earth Environ Sci 216 1-7. DOI : 10.1088/1755-1315/216/1/012001

Dobson M, Frid C. 2009. Ecology of aquatic systems. 2nd ed. Oxford University Press, New York.

Effendie MI. 1997. Biologi perikanan [Biology of Fishery]. Yayasan Pustaka Nusatama, Yogyakarta. [Indonesian]

Ekau W, Aue, H, Pörtner HO, Gilbert D. 2010. Impacts of hypoxia on the structure and processes in pelagic communities (zooplankton, macroinvertebrates and fish). Biogeosciences 7: 1669-1699. DOI: 10.5194/bgd-6-5073-2009

Elviana S, Sunarni S, Maturbongs MR, Sajriawati, Fakhriyyah S. 2019 Mudskipper diversity and its relationship to an environmenta condition in estuary. IOP Conf Ser Earth Environ Sci 343: 012191. DOI: :10.1088/1755-1315/343/1/012191.

Enot WS, Fahri, Annawaty. 2015. Periophthalmus spp. (Gobiidae: Oxudercinae) di habitat mangrove Kabupaten Banggai, Sulawes Tengah Tengah [Periopthalmus spp. (Gobiidae: Oxudercinae) in mangrove habitat at Banggai District, Central Sulawesi]. Proceeding Seminar Nasional Biologi 2015: 117-120. [Indonesian]

Feka NZ, Manzano MG. 2008. The implications of wood exploitation for fish smoking on mangrove ecosystem conservation in the South West Province, Cameroon. Trop Conserv Sci 1 (3): 222-241. DOI 10.1177/194008290800100305

Fishbase. 2018. Fish Identification: Find Species. Retrieved from https://www.fishbase.se/identification/SpeciesList.php?genus=Periop hthalmus

Gholizadeh MH, Melesse AM, Reddi L. 2016. A comprehensive review on water quality parameters estimation using remote sensing techniques. Sensors 16: 1-43. DOI: 10.3390/s16081298

Giomi F, Barausse A, Duarte CM, Booth J, Agusti S, Saderne V, Anton A, Daffonchio D, Fusi M. 2019. Oxygen supersaturation protect coastal marine fauna from ocean warming. Sci Adv 5: eaax1814. DOI: $10.1126 /$ sciadv.aax 1814

Haeril, Purnomo EP. 2019. Management of sustainable coastal areas and small islands based on collaborative management (Case study in Bima Regency, West Nusa Tenggara). Logos J 2 (1): 18-37. DOI 10.22219/LOGOS.Vol2.No1.18-37

Hanifah A, Eddiwan K. 2018. The effect of mangrove forest ecosystems on fishing fishery production in the Rangsang Regency, District of Kepulauan Meranti, Indonesia. MOJ Ecol Environ Sci 3 (6): 407-412.

Hoffmann AA, Hercus MJ. 2000. Environmental stress as an evolutionary force. BioScience 50 (3): 217-226. DOI: 10.641/0006-3568 (2000)050[0217:ESAAEF]2.3.CO;2

Huliselan NV, Wawo M, Tuapattinaja MA, Sahetapy D. 2017. Kondisi sosial ekonomi nelayan kerapu (famili serranidae) di perairan teluk kotania, seram bagian barat, provinsi maluku [Socio-economic condition of grouper fishermen (Serranidae Family) in the waters o, Kotania Bay, West Seram, Maluku Province]. Jurnal TRITON 13 (2): 85-92. [Indonesian]

Indarjo A, Salim G, Zein M, Susiyanti, Soejarwo PA, Nugraeni CD, Bija S, Pham YTH. 2020. Characteristics of von bertalanffy growth, allometric, condition index and mortality of Periophthalmus barbarus in Mangrove and Bekantan Conservation Area (KKMB), Tarakan, North Kalimantan. Indonesian J Mar Sci 25 (1): 31-38. DOI: 10.14710/ik.ijms.25.1.31-38

Ip YK, Randall DJ, Kok TKT, Barzaghi C, Wright PA, Ballantyne JS, Wilson JM, Chew SF. 2004. The giant mudskipper Periophthalmodon schlosseri facilitates active $\mathrm{NH}_{4}{ }^{+}$excretion by increasing acid excretion and decreasing NH3 permeability in the skin. J Exp Biol 207: 787-801. DOI: $10.1242 / \mathrm{jeb} .00788$.

Jaafar Z, Larson HK. 2008. A New Species of Mudskipper, Periophthalmus takita (Teleostei: Gobiidae: Oxudercinae), from Australia, with a key to the genus. Zool Sci 25 (9): 946-952. DOI: 10.2108/zsj.25.946

Jaafar Z, Polgar G, Zamroni Y. 2016. Description of a new species of Periophthalmus (Teleostei: Gobiidae) from the Lesser Sunda Islands. Raffles Bull Zool 64: 278-283.

Kanejiya JR, Solanki DA, Gohil BM. 2017. Distribution of mudskippers in the mudflats of Hathab Coast, Gujarat, India. Cibtech J Zool 6 (2): $1-8$.

Khaironizam MZ, Norma-Rashid Y. 2002. Length-weight relationship of mudskippers (Gobiidae: Oxudercinae) in the coastal areas of Selangor, Malaysia. Naga WorldFish Center Quart 25 (3 \& 4): 20-22.

Kho DN, Tuaputty H, Rumahlatu D, Leiwakabessy F. 2020. Gastropods of mangrove forests in the coastal waters of Ambon island, Indonesia. Eco Env Cons 26 (1): 356-364.

Koprivnikar J, Poulin R. 2009. Effects of temperature, salinity, and water level on the emergence of marine cercariae. Parasitol Res 105 (4): 957-965. DOI: 10.1007/s00436-009-1477-y

Kottelat M. 2013. The fishes of the inland waters of Southeast Asia: A catalogue and core bibliography of the fishes known to occur in freshwaters, mangroves and estuaries. Raffles Bull Zool Suppl 27: 1663.

Kruitwagen G, Hecht T, Pratap HB, Bonga WSE. 2006. Changes in morphology and growth of the mudskipper (Periophthalmus argentilineatus) associated with coastal pollution. Mar Biol 149: 201211. DOI: $10.1007 / \mathrm{s} 00227-005-0178-\mathrm{z}$.

Kruitwagen G, Nagelkerken I, Lugendo BR, Pratap HB, Bonga SEW. 2007. Influence of morphology and amphibious life-style on the feeding ecology of the mudskipper Periophthalmus argentilineatus. J Fish Biol 71: 39-52. DOI: 10.1111/j.1095-8649.2007.01508.x.

Larson HK, Jaafar Z, Lim KKP. 2016. An updated checklist of the gobioid fishes of Singapore. Raffles Bull Zool 34 (Part II): 744-757.

Lee SY, Primavera JH, Dahdouh-Guebas F, McKee K, Bosire JO, Cannicci S, Diele K, Fromard F, Koedam N, Marchand C, Mendelssohn I, Mukherjee N, Record S. 2014. Ecological role and services of tropical mangrove ecosystems: A reassessment. Global Ecol Biogeogr 23: 726-743. DOI: 10.1111/geb.12155.

Mahadevan G, Ravi V, Murugesan P. 2019. Length-weight relationship of a mudskipper Pseudapocryptes elongatus (cuvier, 1816) from Indian Sundarbans. J Bombay Nat Hist Soc 116: 156-159.

Mahadevan G, Ravi V. 2015. Distribution of mudskippers in the mudflats of muthupet, Southeast coast of India. Intl J Fish Aquat Stud 3 (2): 268-272.

Mai HV, Tran LX, Dinh QM, Tran DD, Murata M, Sagara H, Yamada A, Shirai K, Ishimatsu A. 2019. Land invasion by the mudskipper, Periophthalmodon septemradiatus, in fresh and saline waters of the Mekong River. Sci Rep 9: 1-11. DOI: 10.1038/s41598-019-50799-5

Moslen M, Daka, ER. 2017. Length-weight relationship and condition factor of Periopthalmus papilio (Bloch \& Schneider, 1801) obtained from a tidal creek in the Bonny Estuary, Nigeria. J Aqua Fish Manag 1 (1): $1-4$.

Muhtadi A, Ramadhani SF, Yunasfi. 2016. Identification and habitat type of mudskipper (Family: Gobiidae) at the Bali Beach, district of Batu Bara, North Sumatra Province. Biospecies 9 (2): 1-6. DOI: 10.3853/j.0812-7387.11.1989.93

Murdy EO. 1989. A taxonomic revision and cladistic analysis of the oxudercine gobies (Gobiidae: xudercinae). Records of the Australian Museum, Suppl 11: 1-93.

Nugroho BA, Soendjoto MA, Zaini M. 2019. Gastropod density and diversity in the mangrove forest of Pagatan Besar Village, Tanah Laut Regency, Indonesia. Indonesian J Mar Sci 24 (4): 179-185. DOI: 10.14710/ik.ijms.24.4.179-185

Nursyam H. 2017. Aquatic environmental quality survey on turtle conservation at "Bajulmati" Beach, Malang District, East Java, Indonesia. Intl J Sci Res 73 (2): 46-54. DOI: 10.21506/j.ponte.2017.2.3 
Odum E, Barrett GW. 2004. Fundamentals of Ecology, 5th ed. Thomson Brooks/Cole, Belmont, CA.

Pamungkas J. 2017. Capitella ambonensis: A new polychaete species (Annelida: Capitellidae) collected from a mangrove habitat on Ambon Island, Indonesia. Zootaxa 4227 (4): 573-582. DOI 10.11646/zootaxa.4227.4.7

Polgar G, Crosa G. 2009. Multivariate characterization of the habitats of seven species of Malayan mudskippers (Gobiidae: Oxudercinae). Mar Biol 156: 1475-1486. DOI: 10.1007/s00227-009-1187-0

Polgar G, Ghanbarifardi M, Milli S, Agorreta A, Aliabadian M, Esmaeili HR, Khang TF. 2017. Ecomorphological adaptation in three mudskippers (Teleostei: Gobioidei: Gobiidae) from the Persian Gulf and the Gulf of Oman. Hydrobiologia 795: 91-111. DOI: 10.1007/s10750-017-3120-8

Polgar G, Lim R. 2011. Mudskippers: Human use, ecotoxicology and biomonitoring of mangrove and other soft bottom intertidal ecosystems. Institute of Biological Sciences, Institute of Ocean and Earth Sciences, Faculty of Science, University of Malaya Kuala Lumpur. Malaysia.

Polgar G, Zane L, Babbucci M, Barbisan F, Patarnello T, Rüber L, Papetti C. 2014. Phylogeography and demographic history of two widespread Indo-Pacific mudskippers (Gobiidae: Periophthalmus). Mol Phylogenet Evol 73: 161-176. DOI: 10.1016/j.ympev.2014.01.014

Polgar G. 2008. Species-area relationship and potential role as a biomonitor of mangrove communities of Malayan mudskippers. Wetlands Ecol Manag 17 (2): 157-164. DOI: 10.1007/s11273-0089090-x

Polgar G. 2016. First record and conservation value of Periophthalmus malaccensis Eggert from Borneo, with ecological notes on other mudskippers (Teleostei: Gobiidae) in Brunei. Scientia Bruneiana 15: 48-57. DOI: $10.46537 /$ scibru.v15i0.42

Pormansyah, Iqbal M, Setiawan A, Yustian I, Zulkifli H. 2019. A review of recent status on mudskippers (Oxudercine Gobies) in Indonesian waters. Oceanogr Fish Open Access J 9 (4): 001-004. DOI: 10.19080/OFOAJ.2019.09.555769

Quang DM. 2016. Growth and body condition variation of the giant mudskipper Periophthalmodon schlosseri in dry and wet seasons. Tap chi Sinh hoc 38 (3): 352-358. DOI: 10.15625/0866-7160/v38n3.7425

Ravi V. 2011. Habitat loss and population reduction of mudskippers (Family: Gobiidae) from Tamil Nadu, S.E. Coast of India. Marine Biodiversity: Present Status Prospects 5: 37-49. DOI 10.13140/2.1.3123.7128.

Ridho MR, Patriono R, Sholikah M. 2019. Food habits of three species of mudskippers in the Musi River Estuary, South Sumatra, Indonesia. Biodiversitas 20 (8): 2368-2374. DOI: 10.13057/biodiv/d200835.

Roman MR, Brandt SB, Houde ED, Pierson JJ. 2019. Interactive effects of hypoxia and temperature on coastal pelagic zooplankton and fish. Front Mar Sci 6 (139): 1-18. DOI: 10.3389/fmars.2019.00139

Rumahlatu D, Leiwakabessy F. 2017. Biodiversity of gastropoda in the coastal waters of Ambon Island, Indonesia. AACL Bioflux 10 (2): 285-296.

Rumahlatu D, Sangur K, Leuwol AP, Apituley YN, Salmanu SIA, Arini I. 2020. Study of environmental conditions, morphometric and meristic of mudskipper (Periophthalmus) from Ambon Island coastal waters, Indonesia. Indian J Ecol 47 (3): 782-787.

Setyastuti A, Purbiantoro W, Hadiyanto. 2018. Spatial distribution of echinoderms in littoral area of Ambon Island, Eastern Indonesia. Biodiversitas 19 (5): 1919-1925. DOI: 10.13057/biodiv/d190544

Siriwardana C, Cooray AT, Liyanage SS, Koliyabandara SMPA. 2019. Seasonal and spatial variation of dissolved oxygen and nutrients in Padaviya Reservoir, Sri Lanka. J Chem 6: 1-11. DOI: $10.1155 / 2019 / 5405016$

Sofian A, Kusmana C, Fauzi A, Rusdiana O. 2019. Ecosystem servicesbased mangrove management strategies in Indonesia: A review. AACL Bioflux 12 (1): 151-166.

Stevens AM, Gobler CJ. 2018. Interactive effects of acidification, hypoxia, and thermal stress on growth, respiration, and survival of four North Atlantic bivalves. Mar Ecol Progr 604: 143-161. DOI: 10.3354/meps 12725

Sukardjo S, Pratiwi R. 2015. Coastal zone space in Indonesia: Prelude to conflict?. Int J Develop Res 5 (01): 2992-3012.

Sukardjo S. 2004. Fisheries associated with mangrove ecosystem in Indonesia: A view from a mangrove ecologist. Biotropia 23: 13-39. DOI: $10.11598 / \mathrm{btb} .2004 .0 .23 .201$

Sunarni, Melmambessy EHP, Mote N, Rahmatia, Hamuna B. 2019. Length-weight relationship and condition factor of mudskipper Boleophthalmus pectinirostris from Maro Estuary, Merauke Regency, Papua. J Ecol Eng 20 (8): 199-204. DOI: 10.12911/22998993/110841

Supriyati H, Apriliani NS, Luthfi MJ. 2019. Histological study of mudskipper (Periophthalmus gracilis) Gills. Proc Intl Conf Sci Eng 2: $177-179$.

Takita T, Larson HK, Ishimatsu A. 2011. The natural history of mudskippers in northern Australia, with field identification characters. Beagle Rec Mus Art Gall Northern Territory 27: 189-204.

Tanjung RHR, Hamuna B, Alianto. 2019. Assessment of water quality and pollution index in coastal waters of Mimika, Indonesia. J Ecol Eng 20 (2): 87-94. DOI: 10.12911/22998993/95266

Tetelepta JMS, Natan Y, Ongkers OTS, Pattikawa JA. 2018. Some population biology aspects of edible orange mud crab Scylla olivacea (Herbst, 1796) of Kotania Bay, western Seram District, Indonesia. AACL Bioflux 11 (4): 1203-1212.

Varadharajan D, Soundarapandian P, Pushparajan N. 2013. Effect of physico-chemical parameters on crabs biodiversity. J Mar Sci Res Dev 3: 1-11. DOI: 10.4172/2155-9910.1000116

Wahyudewantoro G. 2018. The fish diversity of mangrove waters in Lombok Island, West Nusa Tenggara, Indonesia. Biodiversitas 19 (1): 71-76. DOI: 10.13057/biodiv/d190112

Yuvaraj E, Dharanirajan K, Jayakumar S, Saravanan, Balasubramaniam J. 2017. Distribution and zonation pattern of mangrove forest in Shoal Bay Creek, Andaman Islands, India. Indian J Mar Sci 46 (03): $597-$ 604.

Zaghloul A, Saber M, Abd-El-Hady M. 2019. Physical indicators for pollution detection in terrestrial and aquatic ecosystems. Bull Natl Res Cent 43 (120): 1-6. DOI: 10.1186/s42269-019-0162-2. 